\title{
Universiteit
}

Leiden

The Netherlands

\section{Gruwelijke beelden van plaatsen delict: \\ kijkstrategieën, opgewekte emoties en oordeelsvorming}

Dillen, L.F. van; Vanderveen, G.N.G.

\section{Citation}

Dillen, L. F. van, \& Vanderveen, G. N. G. (2017). Gruwelijke beelden van plaatsen delict: kijkstrategieën, opgewekte emoties en oordeelsvorming. Tijdschrift Voor Criminologie, 59(1-2), 176-193. doi:10.5553/TvC/0165182X2017059102010
Version:
Publisher's Version
License:
Leiden University Non-exclusive license
Downloaded from: $\quad$ https://hdl.handle.net/1887/57386

Note: To cite this publication please use the final published version (if applicable). 


\title{
Gruwelijke beelden van plaatsen delict: kijkstrategieën, opgewekte emoties en oordeelsvorming*
}

\author{
Lotte van Dillen \& Gabry Vanderveen
}

Door middel van eyetracking bekeken de auteurs het kijkgedrag naar foto's van plaatsen delict van 23 deelnemers aan het jaarlijkse congres voor criminologen. De auteurs onderzochten hiernaast negatieve emoties in reactie op de foto's en deelnemers gaven inschattingen van ernst en strafmaat na het lezen van een korte beschrijving van de casus behorende bij de foto's. Vooraf werden individuele verschillen in walgingsgevoeligheid in kaart gebracht. De resultaten lieten een positief verband zien tussen walgingsgevoeligheid, duur en aantal fixaties op zogenaamde emotionele hotspots van de foto's, zoals het bloed en de wond, ervaren emoties tijdens het bekijken van de foto's en de inschatting van ernst en strafmaat. De auteurs bespreken de implicaties van de bevindingen in het kader van toekomstig onderzoek.

\section{Inleiding}

Digitale ontwikkelingen in het documenteren en delen van informatie gaan steeds sneller, en foto's en video's van hoge kwaliteit zijn beter toegankelijk dan ooit. Ook binnen de Nederlandse strafrechtketen maken diverse actoren meer en meer gebruik van nieuwe technologieën voor het verzamelen, analyseren en presenteren van audiovisueel bewijsmateriaal (Dubelaar \& Vanderveen, 2009; Vanderveen, 2011). Daar komt bij dat in de toekomst steeds meer digitaal gewerkt zal worden in de strafrechtketen (Minister van Veiligheid en Justitie, 2016a). De digitalisering van processtukken en het dossier krijgt vooral aandacht voor wat betreft de juridische, technische en organisatorische uitdagingen en consequenties (bijv. Dijkstra e.a., 2016). Soms wordt daarbij gewezen op de (mogelijke) cognitieve gevolgen (bijv. Van Wees, 2015, 803; Minister van Veiligheid en Justitie, 2016b, 16). Empirisch onderzoek naar de sociaalwetenschappelijke effecten van digitalisering van het strafrecht, waaronder op het gebied van ergonomie en cognitie, staat echter nog in de kinderschoenen (Jolij, 2015; 2016).

Onze onderzoeksprojecten richten zich in dit kader op beeldmateriaal. Immers, dankzij de digitalisering van processtukken kunnen, mits de technologie dat toestaat, afbeeldingen, visuele reconstructies en scenario's op verschillende momenten en door verschillende actoren bekeken, getoond en bediscussieerd worden (Schofield \& Fowle, 2013). Grote hoeveelheden complexe informatie kunnen worden overgebracht en ook een bezoek aan een virtuele plaats delict lijkt steeds dichterbij te komen (Bailenson e.a., 2006; Chowdhury, 2016). Hoewel digitalise-

* De auteurs willen de reviewers en (thema)redactie hartelijk danken voor het constructieve commentaar. 
ring nieuwe mogelijkheden biedt, kan zij echter ook (onbedoelde) effecten hebben op mensen, dus ook op politiemedewerkers en juridische professionals. Daarbij doelen we bijvoorbeeld op de confrontatie met beeldmateriaal dat extreem leed of gruwelijkheden toont en belastend kan zijn voor de kijker (bijv. Sollie e.a., 2014). Ook doelen we op de (onbewuste en mogelijk onbedoelde) effecten van het beeldmateriaal op het oordeel over delicten, die in vergelijking met tekstueel of verbaal materiaal anders kunnen zijn.

De (mogelijk) opgewekte emoties door het beeldmateriaal kunnen van invloed zijn op bijvoorbeeld de informatieverwerking en op de attributie van verantwoordelijkheid en schuld (Feigenson, 2016; Bandes \& Salerno, 2014). Vooral in landen met een jurysysteem (en andere procescultuur) wordt hier veel onderzoek naar gedaan. In de Verenigde Staten worden beelden soms niet toegestaan door de rechter of krijgen juryleden instructies (zie Murray, in druk; Robertson, 2015). De resultaten van experimenten, veelal met potentiële juryleden, met de aan- dan wel afwezigheid van (gruwelijk) beeldmateriaal zijn niet eensluidend. Maar verschillende studies vonden dat gruwelijk beeldmateriaal meer negatieve emoties (zoals boosheid en walging) opwekt en een strenger oordeel oplevert over de schuld van de verdachte, de ernst en/of de straf (bijv. Bright \& Goodman-Delahunty, 2011; Edwards \& Mottarella, 2014). Hoe dit gerelateerd is aan hoe mensen kijken naar het beeldmateriaal is onbekend. Ook is niet duidelijk hoe persoonskenmerken, zoals bijvoorbeeld walgingsgevoeligheid, hiermee variëren. Dit is wel relevant, omdat walgingsgevoeligheid een relatie heeft met zowel kijkgedrag als morele oordelen. Zo is gebleken dat individuele variatie in walgingsgevoeligheid kijkgedrag naar walgelijke informatie beïnvloedt (Schienle e.a., 2016). Schienle en collega's zagen dat zowel individuele verschillen in walgingsgevoeligheid als gerapporteerde walging positief samenhingen met het aantal fixaties op walgelijke afbeeldingen (smerige toiletruimten, bedorven voedsel) in vergelijking met neutrale afbeeldingen. Ander experimenteel onderzoek toont aan dat walgingsgevoeligheid positief gerelateerd is aan morele afkeuring van (kleine) overtredingen (Pizarro e.a., 2011; Van Dillen e.a., 2012). Verder heeft een recente meta-analyse aangetoond dat walging, opgeroepen door beeld, maar met name ook door smaak of geur, morele afkeuring kan versterken (Landy \& Goodwin, 2015). Vooral de invloed van geur kan relevant zijn voor onderzoek onder bijvoorbeeld forensisch rechercheurs, die naast de beelden van de plaats delict, ook de bijkomende geuren te verwerken krijgen.

Rekening houdend met de (voornamelijk Angelsaksische) bevindingen wat betreft de effecten van gruwelijk beeldmateriaal kan de digitalisering van visueel bewijsmateriaal potentieel van grote invloed zijn op beslissingen in de hele Nederlandse strafrechtketen. Immers, de digitalisering brengt met zich mee dat beeldmateriaal makkelijker uitgewisseld, gepresenteerd en tegelijkertijd tijdens de zitting bekeken kan worden. Dat betekent bijvoorbeeld dat niet meer gewerkt zal worden met 'zwart-witkopietjes' van letselfoto's en foto's van plaatsen delict, maar met kleurenfoto's waarop ingezoomd kan worden (Vanderveen \& Van Dillen, 2013). Het betekent ook dat (ontlastend) beeldmateriaal makkelijker door de verdediging gepresenteerd kan worden (zie Dijkstra e.a., 2016, 41). Digitalisering maakt dat iedereen tegelijkertijd naar beeldmateriaal kan kijken, wat discussie in de hand 
kan werken over wat (of wie) nu eigenlijk te zien is. De mogelijkheden om bewijs te toetsen nemen dus toe (Malsch, 2013). De digitalisering in combinatie met de groeiende beschikbaarheid van beelden roept nieuwe vraagstukken van openbaarheid en transparantie op, zoals over de wenselijkheid om beelden (i.c. kinderporno) op een openbare zitting te vertonen, 'ten overstaan van de ouders van de kinderen waar het om gaat, het publiek en de pers' (Malsch, 2013, 268). Malsch (2013) betoogt tevens dat er meer ruimte zal komen voor directe emotie. Zij stelt dat meer onderzoek naar de effecten en invloeden van verschillende vormen van presentatie binnen de rechtspraak nodig is.

Inderdaad is nog relatief weinig bekend over hoe visueel bewijsmateriaal de emoties van mensen en daarmee hun oordeel over een delict beïnvloedt. De vraag in dit onderzoek was dan ook welke verbanden en effecten te vinden zijn tussen individuele verschillen in walgingsgevoeligheid enerzijds en inschattingen van ernst en strafmaat van een delict en opgeroepen emoties door beeldmateriaal van een plaats delict anderzijds, en wat hierin de rol is van kijkstrategieën tijdens het bekijken van het beeldmateriaal. Deze kijkstrategieën kunnen bestudeerd worden met eyetracking.

Door middel van een eyetrackingdemonstratie op het jaarlijkse congres van de Nederlandse Vereniging voor Criminologie (NVC) te Leiden op 11 en 12 juni 2015 bekeken we het kijkgedrag van criminologen tijdens de vertoning van foto's van plaatsen delict. Deelnemers werden op dag één van het congres uitgenodigd om zelf eyetracking te ervaren. De eerste bevindingen hiervan werden vervolgens in een plenaire presentatie op dag twee uiteengezet. Met deze opzet wilden we criminologen bewust maken van de relevantie van ons onderzoek en waren we tegelijkertijd in staat om onze hypothesen te toetsen op een relevante doelgroep, namelijk professionals met een criminologische of strafrechtelijke achtergrond dan wel interesse. We richtten ons specifiek op hoelang en hoe vaak deelnemers keken naar specifieke interessegebieden op de foto's. Deze maten geven informatie over de aandacht van deelnemers voor specifieke aspecten van de foto's (Unema e.a., 2005) en zijn tegelijkertijd relatief ongevoelig voor tijdelijke vertekeningen, omdat ze berekend worden over de gehele stimulusduur, zodat ze ook goed te gebruiken zijn in minder gecontroleerde omstandigheden buiten het lab. Op de foto's werden op basis van de literatuur zogenoemde emotionele 'hotspots' gemarkeerd, zoals het bloed en de wond van het slachtoffer. Vooraf werden individuele verschillen in walgingsgevoeligheid in kaart gebracht door middel van de Nederlandse vertaling van de Revised Disgust Sensitivity Scale (DS-R; Haidt e.a., 1994; Olatunji e.a., 2007). We onderzochten verder in welke mate deelnemers negatieve emoties ervoeren tijdens de vertoning van de foto's. Ook gaven deelnemers inschattingen van ernst en strafmaat na het lezen van een korte beschrijving van de casussen behorende bij de foto's. 


\section{Methode}

\section{Deelnemers}

23 Nederlanders namen deel aan het onderzoek (18 vrouw, $\mathrm{M}_{\text {leeftijd }}=35.79$ jaar, $\mathrm{SD}_{\text {leeftijd }}=3.70$ jaar). Alle deelnemers hadden een normaal gezichtsvermogen, waren rechtshandig, en onbekend met het doel van het experiment.

Deelnemers werden geworven tijdens het jaarlijkse congres van de Nederlandse Vereniging voor Criminologie (NVC) in 2015 en waren criminologen (hoogleraren, docenten, promovendi) alsmede geïnteresseerde beleidsmedewerkers en andere professionals. Deelname was op vrijwillige basis. Alle deelnemers gaven vooraf toestemming, nadat hun de globale opzet was uitgelegd. Het experiment was goedgekeurd door de Commissie Ethiek van de Universiteit Leiden.

\section{Ontwerp}

Deelnemers lazen een beschrijving van twee casussen, een met een mannelijk en een met een vrouwelijk moordslachtoffer, en beide zowel met een midrange als met een overzichtsfoto van de plaats delict. Voor het eyetrackinggedeelte werden slechts de foto's van het mannelijke slachtoffer getoond. De voornaamste afhankelijke variabelen waren de deelnemers' kijkstrategieën en ervaren emoties tijdens het waarnemen van de foto's, ernstinschattingen van het delict en straftoemeting. Hiernaast werd individuele variatie in walgingsgevoeligheid meegenomen als continue maat en werd gekeken naar mogelijke verschillen in emoties, oordelen en strafmaat tussen de twee casussen met elk twee foto's.

\section{Stimulus materialen en vragenlijsten}

\section{- Walgingsgevoeligheid}

Deelnemers vulden een Nederlandse vertaling van de DS-R (Haidt e.a., 1994; Olatunji e.a., 2007) in. In deel I gaven deelnemers hun overeenstemming aan met twaalf stellingen (bijv. 'Ik raak de toiletbril van een openbaar toilet helemaal niet aan') door middel van een 0 (waar) of 1 (niet waar). In deel II beoordeelden deelnemers hoe walgelijk ze twaalf specifieke ervaringen vonden (bijv. 'Je ziet iemand per ongeluk een vishaak door zijn vinger steken') op een schaal van 0 (niet vies) tot 4 (erg vies). De somscore van beide delen is gebruikt als maat van walgingsgevoeligheid (alpha $=.71$, range $36-72$ ).

\section{Kijkgedrag naar foto's plaatsen delict}

Voor het beeldmateriaal voor de eyetrackingtaak werden twee foto's (een midrange en een overzichtsfoto; zie appendix A voor de gebruikte foto's) van één plaats delict met een mannelijk moordslachtoffer geselecteerd uit de GRIM-database (Vanderveen \& Van Dillen, in voorbereiding), die in samenwerking met de Politieacademie en het lectoraat Forensisch Onderzoek tot stand is gekomen. De kwalitatief goede foto's betreffen gereconstrueerde maar realistische beelden van verwondingen aan lijken op plaatsen delict en plaatsen delict zelf. De foto's zijn vergelijkbaar met 'echte' originele foto's die (uiteindelijk) in processen-verbaal en dossiers kunnen worden opgenomen, en stellen ons zodoende in staat onze 
ideeën te toetsen in een realistische setting. In eerder onderzoek hebben wij de foto's reeds succesvol ingezet bij onderzoek onder leken en professionals (Van Dillen e.a., in voorbereiding). Het slachtoffer betrof een man van middelbare leeftijd, liggend op bed met zijn ogen open. Te zien was een hoofdwond en een grote hoeveelheid bloed om de wond. De deelnemers bekeken beide foto's van de man, terwijl hun kijkgedrag geregistreerd werd met de eyetracker. Beide foto's werden vijf seconden getoond, en voorafgaand hieraan verscheen steeds een fixatiekruis gedurende 500 ms. Voor de beide foto's werden drie interessegebieden gedefinieerd, waarbij onderscheid werd gemaakt tussen walging oproepende (bloed en wond), neutrale sociale (gezicht) en neutrale niet-sociale interessegebieden (spulletjes in de kamer).

\section{- Oordelen delict}

Voor elk van de twee tekstuele casusbeschrijvingen, waarvan een casus gerelateerd aan de foto's uit de eyetrackingtaak en een casus gerelateerd aan twee niet eerder bekeken foto's met een vrouwelijk slachtoffer, beoordeelden deelnemers op een schaal van 1 (helemaal mee oneens) tot 7 (helemaal mee eens) het delict met zes items, zijnde: 'Ik vind het erg wat er met het slachtoffer gebeurd is', 'De dader moet worden vervolgd voor wat hij heeft gedaan', 'Ik voel sympathie voor dit slachtoffer', 'Ik vind dit gepleegde delict ernstig', 'Het gedrag van de dader is moreel verwerpelijk' en 'Ik vind de verwondingen van dit slachtoffer ernstig.'

\section{- $\quad$ Straftoemeting}

Vervolgens lazen deelnemers voor elk van de twee casussen: 'De dader van dit misdrijf is gepakt en veroordeeld: De rechtbank achtte het tenlastegelegde bewezen en heeft zowel het feit als de dader strafbaar verklaard. Als u op de stoel van de rechter zou zitten en $u$ mag alleen een onvoorwaardelijke gevangenisstraf opleggen, hoe lang zou die gevangenisstraf dan moeten duren in jaren en maanden?', waarna zij de straf in jaren en maanden toewezen (zie Kampen e.a., 2013).

\section{- Emotionele reacties}

$\mathrm{Na}$ het beoordelen van beide casussen bekeken de deelnemers de twee reeds eerder getoonde midrange en overzichtsfoto's van de casus van de man alsmede twee nog niet eerder bekeken midrange en overzichtsfoto's van de casus met de vrouw (zie appendix A). Deze foto's waren tevens geselecteerd uit de hierboven genoemde GRIM-database. Te zien was een vrouw van in de twintig, liggend op bed met een hoofdwond met bloed. Deelnemers gaven voor elke foto aan in welke mate zij de beelden gruwelijk, ernstig, walgelijk, vies en eng vonden op een schaal van 1 (helemaal niet) tot 7 (heel erg). Een hogere score duidt zodoende intensere emoties aan.

\section{Apparatuur}

Het onderzoek werd uitgevoerd in een ruimte van de Faculteit Rechtsgeleerdheid van de Universiteit Leiden op een 15,6' laptop, met een resolutie van $1.920 \mathrm{x}$ 1.080 pixels en met Qualtrics survey software. Oogbewegingen werden geregis- 
treerd door middel van een Tobii X2-60 Eye Tracker (Tobii Technology, Stockholm, Zweden; zie voor de exacte methode Van Dillen e.a., in druk).

\section{Procedure}

Het onderzoek betrof een demonstratie van de mogelijkheden van eyetracking tijdens het congres. Deelnemers konden op elk moment meedoen aan het onderzoek. Het onderzoek werd afgenomen in een regulier onderwijslokaal zonder speciale maatregelen voor het optimaliseren van eyetrackingonderzoek. Dit betekende dat de belichting niet gelijkmatig was, dat mensen vrij konden in- en uitlopen en dat geluiden van buitenaf in de ruimte doordrongen. Omdat dataverzameling slechts voor de duur van enkele uren mogelijk was en afhankelijk was van de vrijwillige deelname van congresbezoekers, was de steekproef kleiner dan oorspronkelijk beoogd. In figuur 1 staat een schematische weergave van de indeling van de onderzoeksruimte.

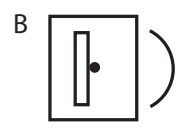

A
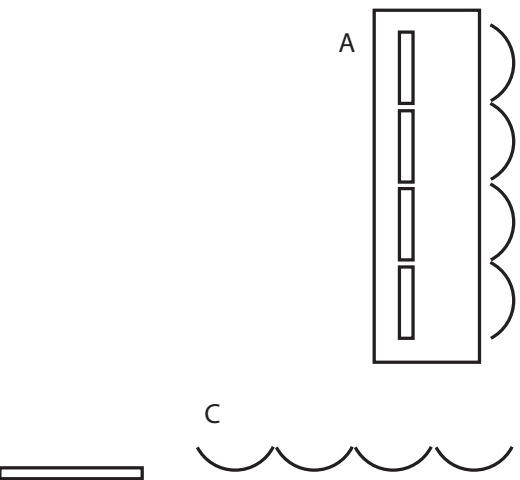

Figuur 1 Schematische weergave van de onderzoeksruimte. Deelnemers namen eerst plaats achter een van vier laptops $(A)$ voor het invullen van de walgingsgevoeligheidsvragenlijst, waarna zij op een aparte laptop (B) een voor een het eyetrackinggedeelte uitvoerden. Vervolgens namen zij weer plaats achter de oorspronkelijke laptop $(A)$ voor de emotieoordelen over de foto's, en de oordelen over het delict en straftoemeting in de casus als geheel. Deelnemers die niet direct konden beginnen aan het experiment konden wachten naast de ingang (C).

Op vier laptops (A in figuur 1) lazen deelnemers eerst een korte introductie waarin hun werd verteld dat zij mogelijk schokkende beelden zouden bekijken en 
beoordelen. ${ }^{1} \mathrm{Na}$ instemming met deelname vulden deelnemers vervolgens eerst de walgingsgevoeligheidsvragen in, waarna zij op een afzonderlijke laptop ( $B$ in figuur 1) de eyetrackingtaak uitvoerden met de twee foto's van de plaats delict met het mannelijke slachtoffer. Omdat slechts één eyetracker beschikbaar was, is gekozen om voor het eyetrackinggedeelte alleen de foto's van het mannelijke slachtoffer te tonen, om zo de doorstroom van deelnemers te optimaliseren. Deelnemers werden individueel getest en werden op ongeveer $65 \mathrm{~cm}$ recht voor de eyetracker geplaatst, waarna een standaard 9-punts kalibratie uitgevoerd werd. Deelnemers werd gevraagd te blijven zitten gedurende de taak en niet van het scherm weg te kijken, waarna verdere instructies op het computerscherm werden gegeven. Beide foto's werden vijf seconden getoond, en voorafgaand hieraan verscheen steeds een fixatiekruis gedurende $500 \mathrm{~ms}$. Na het bekijken van de foto's namen de deelnemers weer achter een van de andere vier laptops plaats (A in figuur 1). Deelnemers lazen een korte beschrijving van de casus gerelateerd aan de foto's van het mannelijke slachtoffer die zij reeds tijdens de eyetrackingtaak hadden gezien (zie appendix B), en beoordeelden vervolgens de ernst van het delict en kenden een straf toe. Hetzelfde deden de deelnemers vervolgens na het lezen van een vergelijkbare korte beschrijving van een nieuwe casus met een vrouwelijk slachtoffer (zie appendix B). Hierna bekeken de deelnemers opnieuw de beide foto's van de plaats delict met het mannelijke slachtoffer uit de eyetrackingtaak, alsmede twee vergelijkbare foto's (een midrange en een overzichtsfoto) van de plaats delict uit de casus met het vrouwelijke slachtoffer (zie appendix A) en gaven op elk van de foto's hun emotionele reacties. Tot slot rapporteerden deelnemers nog enkele demografische gegevens (d.w.z. leeftijd, sekse, huidige werk en ervaring met gruwelijke beelden en plaatsen delict) en werden vervolgens bedankt voor hun bijdrage. Wanneer alle laptops bezet waren, werd deelnemers gevraagd bij de ingang te wachten of later terug te komen (zie $C$ in figuur 1 ). Tijdens een plenaire presentatie op de tweede dag van het congres werd aan deelnemers en andere belangstellenden het daadwerkelijke doel van het onderzoek uitgelegd en werd een globaal overzicht van de resultaten besproken, alsmede implicaties voor onderzoek in de strafrechtketen.

\section{Databewerking en analyse}

Voor de databewerking en analyses werd Tobii Studio (versie 3.2.1) gebruikt in combinatie met Microsoft Excel 2010 en SPSS 21 (IBM). De ruwe eyetrackingdatapunten werden vertaald naar verschillende indices van kijkgedrag door middel van de Tobii Velocity-Threshold Identification (I-VT) Filter. Fixaties werden gedefinieerd als een serie opvolgende kijkcoördinaten, binnen een diameter met een visuele hoek van $0.5^{\circ}$ voor de duur van minimaal $60 \mathrm{~ms}$ (Olsen, 2012). Omdat de belichting ongelijkmatig was en hierdoor kalibratie niet optimaal kon worden uitgevoerd, werd alleen gekeken naar de gemiddelde fixatieduur en het totaal aantal fixaties, die relatief ongevoelig zijn voor het tijdelijk wegvallen van het trackingsignaal en andere vertekeningen. Beide maten reflecteren hoelang iemand moed-

1 Deze waarschuwing heeft niet geleid tot het afzien van deelname en de variatie in walgingsgevoeligheid is behoorlijk. 
willig naar een bepaald aspect van de afbeelding kijkt, en zodoende iemands aandacht voor bepaalde informatie. Omdat niet iedere deelnemer op elk interessegebied van elke foto fixeerde, werd fixatieduur geanalyseerd per interessegebied. Voor de statistische analyses werd gebruik gemaakt van Generalized Linear Mixed Models voor continue maten en Generalized Estimating Equations voor proportiematen, waarbij gecorrigeerd werd voor onderling samenhangende datapunten binnen deelnemers. Voordeel is verder dat deze analysetechnieken relatief ongevoelig zijn voor ontbrekende datapunten. Voorspeller in onze modellen was de continue variabele walgingsgevoeligheid en de factoren casus (mannelijk versus vrouwelijk slachtoffer) en foto (midrange, overzicht) werden als voorspeller toegevoegd wanneer dit relevant was. Significante interacties werden verder geanalyseerd door aparte vergelijkingen van walgingsgevoeligheid binnen de verschillende niveaus van de betreffende factor, of van de geschatte gemiddelden van de betreffende factor voor relatief laaggevoelige deelnemers (geschat op een standaarddeviatie onder de gemiddelde walgingsgevoeligheidscore) en relatief hooggevoelige deelnemers (geschat op een standaarddeviatie boven de gemiddelde walgingsgevoeligheidscore) conform de richtlijnen voor het interpreteren van interacties tussen dichotome en continue variabelen (Tabachnik \& Fidell, 2001). Effectgroottes van verschillen tussen (geschatte) gemiddelden worden gerapporteerd in de vorm van Cohen's d conform de richtlijnen van Taylor (2014) en Hedges (2007) voor het berekenen van effectgroottes in mixed models-analyses.

\section{Resultaten}

\section{Emotionele reacties op het beeldmateriaal}

Een overzicht van de gemiddelden en standaarddeviaties van elk van de gerapporteerde emoties is weergegeven in tabel 1 . Analyse van de emotionele reacties op de vier foto's gaf significante hoofdeffecten van walgingsgevoeligheid, $F(1$, $5495)=16.24$, $\mathrm{p}<.001$, en casus, $\mathrm{F}(1,5495)=110.26$, $\mathrm{p}<.001$, alsmede een interactie van casus en walgingsgevoeligheid, $F(1,5495)=8.08, p=.004$. Over het algemeen waren emotionele reacties op de foto's van de casus met de vrouw minder intens $(\mathrm{M}=2.83, \mathrm{SE}=.21)$ dan op de foto's van de casus met de man $(\mathrm{M}=3.19, \mathrm{SE}=$. 21 , CI [.29; .43]). Deze invloed van casus op emoties was echter sterker voor relatief hoog walgingsgevoelige deelnemers, $\mathrm{F}(1,5495)=89.01, \mathrm{p}<.001, \mathrm{CI}[.37 ; .56]$, Cohen's $d=.23$, dan voor relatief minder gevoelige deelnemers, $F(1,5495)=29.32$, $\mathrm{p}<.001$, CI $[.17$; .36], Cohen's $d=.13$. Figuur 2a biedt een visuele weergave van dit patroon.

\section{Oordelen ernst delict}

Een overzicht van de gemiddelden en standaarddeviaties van elk van de ernstoordelen is weergegeven in tabel 1 . Een vergelijkbare analyse als hierboven met casus en walgingsgevoeligheid van de oordelen liet een hoofdeffect van casus zien, $\mathrm{F}(1$, $5495)=191.40, \mathrm{p}<.001$, alsmede een interactie van casus met walgingsgevoeligheid, $\mathrm{F}(1,5495)=30.01, \mathrm{p}<.001$. De casus met het vrouwelijke slachtoffer werd als 
Tabel 1 Gemiddelden en standaarddeviaties (M, SD) en 95\%betrouwbaarheidsintervallen (BI) van de verschillende gerapporteerde emoties (links) en delictsoordelen (rechts)

\begin{tabular}{|c|c|c|c|c|c|}
\hline Emoties & $M(S D)$ & $95 \% \mathrm{BI}$ & Oordelen & $M(S D)$ & $95 \% \mathrm{BI}$ \\
\hline Gruwelijk & $3.32(1.73)$ & $(2.75,3.88)$ & Erg voor slachtoffer & $5.74(1.89)$ & $(5.37,6.11)$ \\
\hline Ernstig & $4.47(1.69)$ & $(3.90,5.03)$ & Dader moet vervolgd & $5.98(1.24)$ & $(5.6 \mathrm{I}, 6.35)$ \\
\hline Walgelijk & $2.65(1.52)$ & $(2.09,3.22)$ & Sympathie slachtoffer & $4.63(1.80)$ & $(4.26,5.00)$ \\
\hline Vies & $2.21(1.49)$ & $(1.64,2.77)$ & Delict is ernstig & $5.98(0.92)$ & $(5.61,6.35)$ \\
\hline \multirow[t]{2}{*}{ Eng } & $2.42(1.73)$ & $(1.86,2.99)$ & Moreel verwerpelijk & $5.35(1.17)$ & $(4.98,5.72)$ \\
\hline & & & Verwondingen ernstig & $5.52(1.44)$ & $(5.15,5.89)$ \\
\hline
\end{tabular}

ernstiger beoordeeld $(M=5.74, S D=1.2)$ dan de casus met de man ( $M=5.53$, $\mathrm{SD}=1.4$; CI $[.35 ; .47])$. Hiernaast had casus een significant grotere invloed op de oordelen van relatief hoog walgingsgevoelige deelnemers, $F(1,5495)=186.49$, $\mathrm{p}<$. 001, CI $[.49 ; .66]$, Cohen's $\mathrm{d}=.33$, dan relatief laaggevoelige deelnemers, $\mathrm{F}(1$, 5495)=34.91, p<.001, CI [.17; .33], Cohen's d=.14. Figuur $2 \mathrm{~b}$ biedt een visuele weergave van dit patroon.

\section{Straftoemeting}

Zeven deelnemers hadden geen straf toegewezen, waardoor er voor de analyse van deze maat zestien deelnemers waren. Analyse van straftoemeting als functie van walgingsgevoeligheid en casus liet een hoofdeffect zien van casus, $F(1$, $3822)=10.59, \mathrm{p}=.001$, alsmede een interactie tussen casus en walgingsgevoeligheid, $\mathrm{F}(1,3822)=678.12$, $\mathrm{p}<.001$. Deelnemers kenden gemiddeld een hogere straf toe voor de moord op de man $(M=10.29$ jaar, $S E=1.20)$ dan voor de moord op de vrouw (M=10.06 jaar, $\mathrm{SE}=1.14, \mathrm{~B}=.23$, CI [.09: .36], Cohen's $\mathrm{d}=.16$. Voor de moord op de man was walgingsgevoeligheid bovendien positief gerelateerd aan de straftoemeting, $\mathrm{B}=2.90, \mathrm{SE}=1.20, \mathrm{t}(14.03)=2.41, \mathrm{p}=.030, \mathrm{CI}[.32 ; 5.48]$, terwijl dit voor de moord op de vrouw niet het geval was, $\mathrm{t}(14.03)=.817, \mathrm{p}=.427$ (zie figuur $2 \mathrm{c}$ ). 

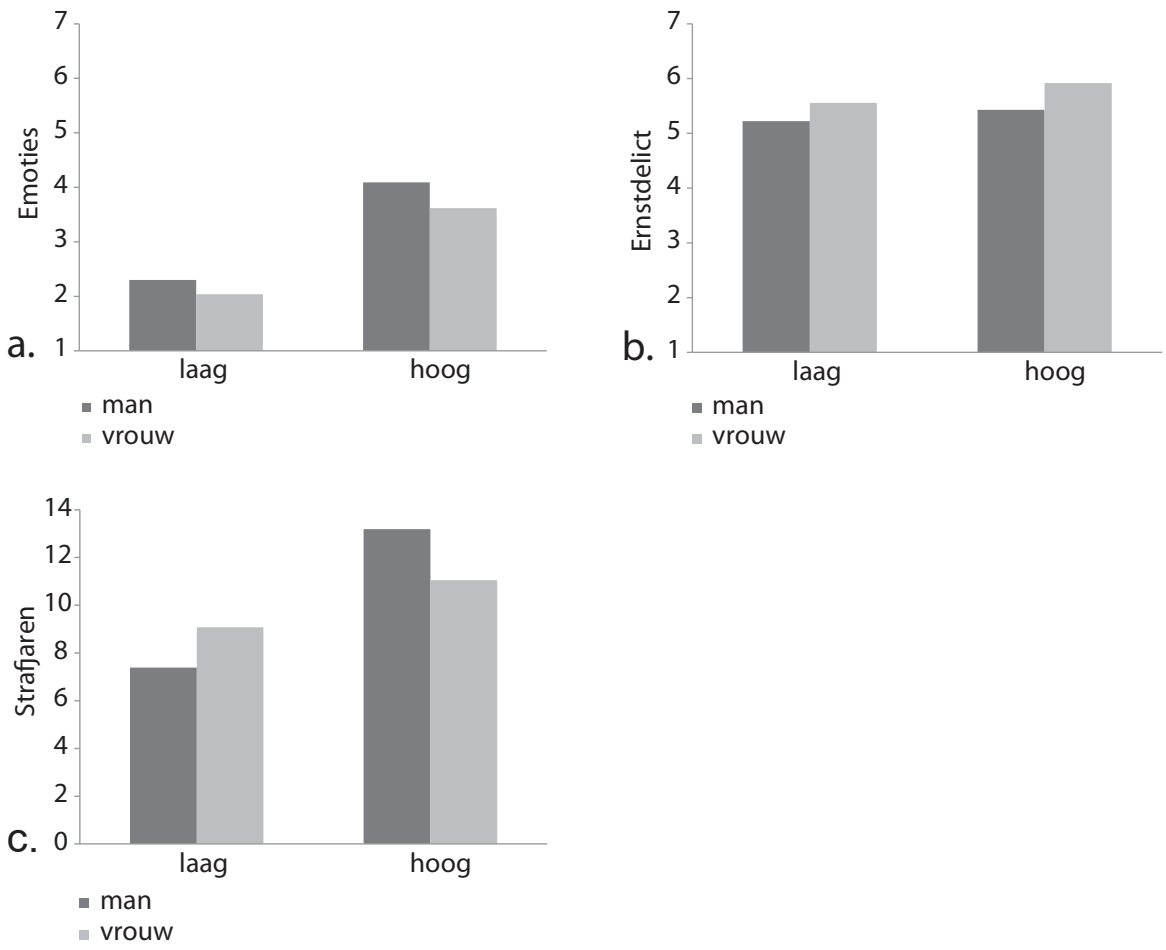

Figuur 2 Geschatte gemiddelden op een schaal van 1 helemaal niet tot 7 heel erg van emoties (a) en ernstoordelen delict (b), en straftoemeting in jaren (c), als functie van casus (man, vrouw) en walgingsgevoeligheid op een standaarddeviatie onder het gemiddelde (laag) en een standaarddeviatie boven het gemiddelde (hoog).

Fixatieduur

Voor de gemiddelde fixatieduur op bloed bekeken we de invloed van foto (midrange, overzicht) en walgingsgevoeligheid. Deze analyse gaf een interactie van foto met walgingsgevoeligheid, $\mathrm{F}(1,21)=4.57, \mathrm{p}=.040$. Voor de midrange foto was er een marginaal effect van walgingsgevoeligheid en gold: hoe gevoeliger de deelnemers, hoe langer zij gemiddeld op het bloed fixeerden, $\mathrm{B}=.08, \mathrm{SE}=.053$, $\mathrm{t}(21)=2.19, \mathrm{p}=.059, \mathrm{CI}[-.003 ; .16]$. Voor de overzichtsfoto was dit verband er niet, $\mathrm{t}(21)=-1.12, \mathrm{p}=.275$. Vergelijkbare analyses van de fixatieduur op de andere interessegebieden (gezicht en spulletjes) leverden geen significante resultaten op ( $p$ >.30). Zie figuur 3 voor een visualisatie van de fixaties op de midrange foto. 

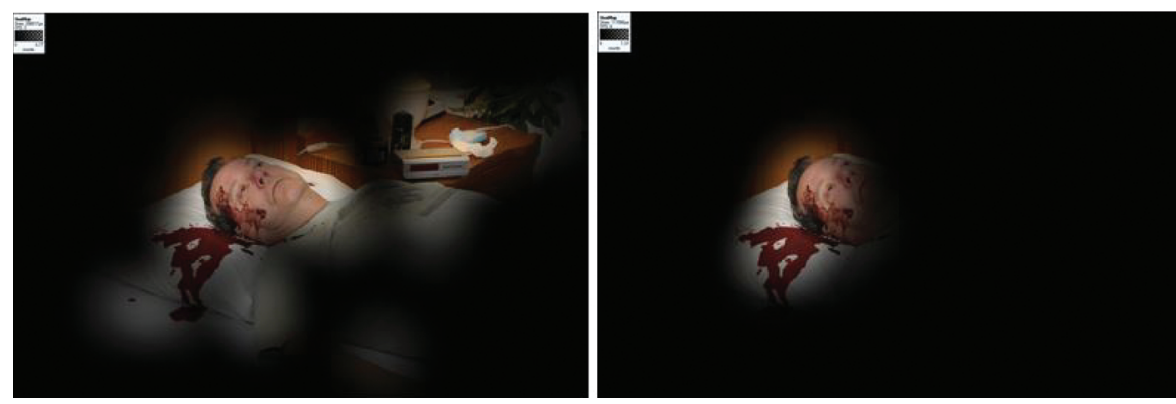

Figuur 3 Visualisatie van gemiddelde fixatieduur voor laag (links) versus hoog (rechts) walgingsgevoelige deelnemers op de midrange foto. Voor visualisatiedoeleinden zijn laaggevoelige en hooggevoelige deelnemers gegroepeerd aan de hand van een median split. De oorspronkelijke foto is weergegeven in appendix $A(a)$.

\section{Aantal fixaties}

Voor het aantal fixaties op bloed vonden we een hoofdeffect van foto, Wald $(1)=9.44, p=.002$, en walgingsgevoeligheid, Wald(1)=6.07, $\mathrm{p}=.014$, alsmede een interactie van foto met walgingsgevoeligheid, Wald $(1)=6.35, p=.012$. Deelnemers fixeerden over het algemeen vaker op het bloed op de midrange foto dan op de overzichtsfoto, $\mathrm{B}=.70, \mathrm{SE}=.23, \mathrm{CI}[.25 ; 1.14]$. Voor de overzichtsfoto gold verder: hoe gevoeliger de deelnemers, hoe vaker zij op het bloed fixeerden, $\mathrm{B}=.68$, $\mathrm{SE}=.12$, Wald(1)=31.64, $\mathrm{p}<.001, \mathrm{CI}[.45 ; .92]$. Dit verband was niet aanwezig voor de casus met de midrange foto, $\mathrm{B}=-.013, \mathrm{SE}=.25$, Wald $(1)=.003, \mathrm{p}=.959$.

Vergelijkbare analyses van aantal fixaties op de andere interessegebieden (gezicht en spulletjes) leverden wederom geen significante resultaten op ( $p>45)$. Zie figuur 4 voor een visualisatie.
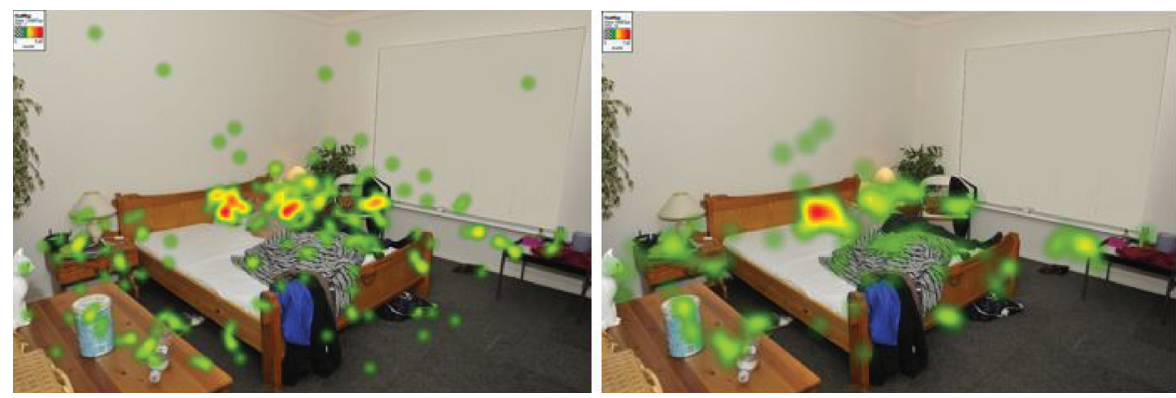

Figuur 4 Heatmaps van aantal fixaties op de overzichtsfoto voor deelnemers met een lage walgingsgevoeligheidscore (links) versus een hoge walgingsgevoeligheidscore (rechts). Hoe roder de kleur, hoe meer fixaties binnen dat gebied. Voor visualisatiedoeleinden zijn laaggevoelige en hooggevoelige deelnemers gegroepeerd aan de hand van een median split. De oorspronkelijke foto is weergegeven in appendix $A(b)$. 


\section{Discussie}

De centrale vraag was welke verbanden er bestaan tussen individuele verschillen in walgingsgevoeligheid enerzijds en opgeroepen emoties door foto's van een plaats delict, inschattingen van ernst en strafmaat van een delict anderzijds, en wat daarbij de rol is van specifieke kijkstrategieën naar foto's van de plaats delict. Eerder (Angelsaksisch) onderzoek naar de effecten van gruwelijk beeldmateriaal keek weliswaar naar opgewekte walging, maar niet naar walgingsgevoeligheid (Bright \& Goodman-Delahunty, 2011; Edwards \& Mottarella 2014). Verder is wel al eyetrackingonderzoek gedaan naar de invloed van walging op kijkgedrag (Schienle e.a., 2016), maar niet binnen een strafrechtelijke context.

Onze resultaten vertoonden allereerst een positief verband tussen walgingsgevoeligheid, ervaren emoties tijdens het bekijken van foto's van de plaats delict en strafmaat, en in mindere mate, ernstinschattingen. Vergeleken met deelnemers die relatief minder gevoelig waren voor walging, beoordeelden meer gevoelige deelnemers het delict als ernstiger en wezen zij hogere straffen toe, en zij rapporteerden meer negatieve emoties in reactie op de foto's. Analyse van de eyetrackingdata liet verder zien dat kijkgedrag varieerde met walgingsgevoeligheid, zodat walgingsgevoelige deelnemers langer en vaker focusten op het bloed van het slachtoffer dan relatief ongevoelige deelnemers. Dit laatste komt overeen met eerder eyetrackingonderzoek, dat een verband liet zien tussen walgingsgevoeligheid en het aantal fixaties op walgelijke beelden (Schienle e.a., 2016).

Onze bevindingen impliceren dat er belangrijke individuele variatie bestaat in de ervaring en invloed van negatieve emoties op oordeelsvorming en strafmaat, en dat bepaalde kijkstrategieën hierin mogelijk een rol spelen. Toekomstig onderzoek, in navolging van eerder Angelsaksisch onderzoek, zal moeten uitwijzen in hoeverre specifieke instructies effectief kunnen zijn om emotionele vertekeningen tegen te gaan bij verschillende walgingsgevoeligheid. In een eerste verkenning hiervan in een meer gecontroleerde setting, waarbij leken geïnstrueerd werden om bijkomende emoties te onderdrukken, zagen we dat deze instructies inderdaad effectief kunnen zijn om emotionele vertekeningen op ernstinschattingen en strafmaat te controleren, en - belangrijker nog - dat deze strategieën bewust geïnitieerd kunnen worden (Van Dillen e.a., in voorbereiding). We zagen echter ook dat het succes van deze strategie afhing van individuele walgingsgevoeligheid, waarbij laaggevoelige deelnemers er beduidend beter in slaagden om emotionele invloeden te reguleren dan hooggevoelige deelnemers. Dit impliceert niet per se dat hooggevoelige deelnemers ongevoelig zijn voor instructie, maar wel dat maatwerk geboden is.

Onze huidige bevindingen illustreren verder dat ook de aard van het beeldmateriaal van invloed is op de mate waarin emotionele reacties inschattingen en evaluaties van plaatsen delict kleuren. Zo zagen we met name een effect op fixatieduur op de midrange foto, waar de wond en het bloed van het slachtoffer een relatief groter deel van de foto betroffen, terwijl we juist een invloed van walgingsgevoeligheid op aantal fixaties zagen van de overzichtsfoto, waarop relatief meerdere interessegebieden weergegeven waren, en waarop dus meer verschillende fixaties gemaakt konden worden. Ook zagen we variatie als functie van casus. Hoewel we 
hier vooraf geen duidelijke voorspellingen over hadden, bleek walgingsgevoeligheid meer van invloed op de evaluaties van de casus met het mannelijke slachtoffer dan met het vrouwelijke slachtoffer. Een mogelijke verklaring is dat de deelnemers langer gekeken hadden naar beeldmateriaal van het mannelijke slachtoffer, aangezien omwille van efficiëntie alleen deze foto's waren opgenomen in de eyetrackingtaak. Een andere verklaring is dat er meer bloed te zien was op de foto's van het mannelijke slachtoffer, hetgeen invloeden van walgingsgevoeligheid verder versterkt kan hebben. Vervolgonderzoek waarin aspecten van het beeld en de casus meer systematisch worden gevarieerd, kan hierover meer duidelijkheid geven.

Het huidige onderzoek betrof een demonstratie tijdens het jaarlijkse congres van Nederlandse criminologen. Deelnemers konden gedurende de eerste dag van het congres op elk moment binnenlopen om deel te nemen. Desalniettemin was de steekproef klein in verhouding tot wat bij meer gecontroleerde experimenten conventioneel is, waardoor uitkomsten van procesanalyses, zoals het toetsen van mediatie door kijkgedrag van de invloed van walgingsgevoeligheid op emoties, ernstinschattingen en strafmaat onbetrouwbaar zijn. Ook liet een aanzienlijk deel van de deelnemers na om een concrete gevangenisstraf te adviseren, bijvoorbeeld omdat men vond dat hiervoor onvoldoende informatie beschikbaar was. De huidige bevindingen dienen dan ook met enige voorzichtigheid te worden geïnterpreteerd en vervolgonderzoek met grotere steekproeven is nodig om aanvullende conclusies te kunnen trekken. Desalniettemin is het opmerkelijk dat onder suboptimale omstandigheden binnen de huidige steekproef van deelnemers met relevante (onderzoeks)expertise op het gebied van strafrecht en/of criminologie eerdere effecten van walgingsgevoeligheid op oordelen gerepliceerd konden worden. In de Angelsaksische wereld wordt gewerkt met instructies aan juryleden, maar welke instructies al dan niet effectief zijn en waarom is niet duidelijk (Sklansky, 2013). Daarnaast kan een rechter of andere actor in de keten, en tijdens de zitting zelf, geconfronteerd worden met beeldmateriaal dat (uiteindelijk) uitgesloten wordt vanwege het onrechtmatig verkrijgen daarvan. Ook voor rechters is het moeilijk om uitgesloten bewijs geen effect te laten hebben op hun oordelen en beslissingen (Wistrich e.a., 2005). In navolging van Salerno en Bottoms (2009), die pleiten voor meer onderzoek naar de hersenactiviteit en de rol van opgewekte emoties bij beoordelingsprocessen, menen wij dat experimenteel onderzoek naar kijkgedrag en kijkstrategieën belangrijke en relevante inzichten kan geven. Daarnaast denken wij net als Jolij $(2015 ; 2016)$ dat onderzoek en evaluaties in de praktijk nodig zijn. De digitalisering van het strafrecht heeft immers niet alleen juridische, technische en organisatorische consequenties, maar ook cognitieve effecten. Eerder onderzoek laat zien dat beeldmateriaal mogelijk (andere) effecten op opgewekte emoties en oordelen heeft, en door de digitalisering zal (kleurig) beeldmateriaal een grotere rol krijgen in het strafproces. Beslissingsprocessen van actoren in de keten zullen hierdoor worden beïnvloed.

In toekomstig onderzoek willen wij dan ook voortbouwen op onze eerdere experimenten, meer specifiek onder professionals in de opsporing en juridische professionals. Relevante vragen hierbij zijn: Welke kijkstrategieën hanteren professionals? Verschillen zij hierin van leken? Hoe beïnvloeden bepaalde kijkstrategieën 
de informatieverwerking op de plaats delict of van beeldmateriaal van de plaats delict, worden bijvoorbeeld bepaalde details herinnerd? Hoe beïnvloeden deze kijkstrategieën de keuze om bepaalde beelden op te nemen in het proces-verbaal? Welke effecten hebben deze strategieën op oordelen en beslissingen over het delict?

\section{Literatuur}

Bailenson, J.N., Blascovich, J., Beall, A.C. \& Noveck, B. (2006). Courtroom applications of virtual environments, immersive virtual environments, and collaborative virtual environments. Law \& Policy, 28(2), 249-270.

Bandes, S. \& Salerno, J. (2014). Emotion, proof, and prejudice. The cognitive science of gruesome photos and victim impact statements. Arizona State Law Journal, 46, 1003-1056.

Bright, D.A. \& Goodman-Delahunty, J. (2011). Mock juror decision making in a civil negligence trial. The impact of gruesome evidence, injury severity, and information processing route. Psychiatry, Psychology and Law, 18, 439-459.

Chowdhury, M. (2016). Virtual reality robots could help teleport juries to crime scenes. The Conversation UK. Verkregen op 26 september via theconversation.com/virtual-realityrobots-could-help-teleport-juries-to-crime-scenes-64382.

Dijkstra, M., Joosten, S., Stamhuis, E. \& Visser, M. (2016). Beginselen digitaal. Digitalisering en de beginselen van de strafrechtspleging. Rapport van een verkennend onderzoek in opdracht van het WODC. Heerlen/Den Haag: Open Universiteit/WODC.

Dillen, L.F. van, Blokker, R. \& Vanderveen, G.N.G. (in voorbereiding). Disgust at the crime scene. How disgust in response to gruesome crime scene images shapes gaze behavior, crime evaluations and punitive judgments among professionals and lay people.

Dillen, L.F. van, Wal, R.C. van der \& Bos, K. van den (2012). On the role of attention and emotion in morality. Attentional control modulates unrelated disgust in moral judgments. Personality and Social Psychology Bulletin, 38, 1222-1231.

Dillen, L.F. van, Enter, D., Peters, L.P.M., Dijk, W.W. van \& Rotteveel, M. (in druk). Moral fixations: the role of moral integrity and social anxiety in the selective avoidance of social threat. Biological Psychology.

Dubelaar, M.J. \& Vanderveen, G.N.G. (2009). Beeld en geluid in het strafproces; implicaties van de opkomst van (audio)visuele technieken en materialen voor communicatie en besluitvorming in de strafrechtspraktijk. Nederlands Juristenblad, 84, 7-16.

Edwards, E.R. \& Mottarella, K.E. (2014). Preserving the right to a fair trial. An examination of prejudicial value of visual and auditory evidence. North American Journal of Psychology, 16(2), 397-414.

Feigenson, N. (2016). Jurors' emotions and judgments of legal responsibility and blame. What does the experimental research tell us? Emotion Review, 8(1), 26-31.

Haidt, J., McCauley, C. \& Rozin, P. (1994). Individual differences in sensitivity to disgust. A scale sampling seven domains of disgust elicitors. Personality and Individual Differences, 16, 701-713.

Hedges, L.V. (2007). Effect sizes in cluster-randomized designs. Journal of Educational and Behavioral Statistics, 32, 341-370.

Jolij, J. (2015). De cognitieve ergonomie van het digitale dossier. Trema: Tijdschrift voor de Rechterlijke Macht, 38(8), 240-244. 
Jolij, J. (2016). Gebruikerservaring, 'cognitive engineering' en het digitale dossier. Trema: Tijdschrift voor de Rechterlijke Macht, 4, 125-129.

Kampen, M., Keijser, J. de \& Schoep, A. (2013). Het effect van de slachtofferverklaring op straftoemeting: een experimenteel onderzoek onder rechtenstudenten. Tijdschrift voor Criminologie, 55, 24-43.

Landy, J. F., \& Goodwin, G. P. (2015). Does Incidental Disgust Amplify Moral Judgment? A Meta-Analytic Review of Experimental Evidence. Perspectives on Psychological Science, 10, 518-536.

Malsch, M. (2013). Een transparanter strafrechtssysteem in Nederland? Mogelijkheden en onmogelijkheden van meer openbaarheid. In: D. Broeders, C.J.E.J. Prins, H. Griffioen, P. Jonkers, M. Bokhorst \& M. Sax (eds.). Speelruimte voor transparantere rechtspraak. Amsterdam: Amsterdam University Press, 265-295.

Minister van Veiligheid en Justitie (2016a). Voortgangsrapport Versterking Prestaties Strafrechtketen (Bijlage). Kamerstukken II 2015/16, 29279, 333.

Minister van Veiligheid en Justitie (2016b). Naar digitaal werken in de strafrechtsketen. Perspectief en richting (Bijlage). Kamerstukken II 2015/16, 29279, 298, blg-685454.

Murray, M.D. (in druk). The ethics of visual legal rhetoric. Legal Communication \& Rhetoric: JALWD, 13. Geraadpleegd via SSRN: ssrn.com/abstract=2655707 of dx.doi.org/ 10.2139/ssrn.2655707.

Olatunji, B.O., Williams, N.L., Tolin, D.F., Abramowitz, J.S., Sawchuk, C.N., Lohr, J.M. \& Elwood, L.S. (2007). The Disgust Scale: item analysis, factor structure, and suggestions for refinement. Psychological Assessment, 19, 281-297.

Olsen, A. (2012). The Tobii I-VT Fixation Filter. Tobii Technology.

Pizarro, D., Inbar, Y. \& Helion, C. (2011). On disgust and moral judgment. Emotion Review, 3, 267-268.

Robertson, M.S. (2015). Guilty as photoshopped: an examination of recent case law and scholarship regarding the use of non-probative images in the courtroom. Washburn Law Journal, 55(3), 731-758.

Salerno, J.M. \& Bottoms, B.L. (2009). Emotional evidence and jurors' judgments: the promise of neuroscience for informing psychology and law. Behavioral Sciences \& the Law, 27(2), 273-296.

Schienle, A., Übel, S., Gremsl, A., Schöngassner, F. \& Körner, C. (2016). Disgust proneness and the perception of disgust-evoking pictures. Journal of Psychophysiology, 30(3), 124-129.

Sklansky, D. A. (2013) Evidentiary Instructions and the Jury as Other. Stanford Law Review, 65, 407.

Schofield, D. \& Fowle, K.G. (2013). Technology corner: visualising forensic data. Evidence (Part 1). Journal of Digital Forensics, Security and Law, 8(1), 73-90.

Sollie, H., Kop, N. \& Euwema, M. (2014). Kinderpornorechercheurs en hun mentale weerbaarheid. Tijdschrift voor Criminologie, 56(4), 87-114.

Tabachnick, B.G. \& Fidell, L.S. (2001). Using multivariate statistics (Vol. 4). Boston, MA: Allyn \& Bacon.

Taylor, A. (2015). Standardised effect size in a mixed/multilevel model. Overgenomen uit: http://www.psy.mq.edu.au/psystat/documents/standardised_effect_size_in_mixed_ ML_models.pdf

Unema, P.J.A., Pannasch, S., Joos, M. \& Velichkovsky, B.M. (2005). Time course of information processing during scene perception. Visual Cognition, 12, 473-494.

Vanderveen, G.N.G. (2011). Beeldmateriaal in de Nederlandse strafrechtsketen. Justitiële verkenningen, 37(7), 10-28. 
Vanderveen, G.N.G. \& Dillen, L. van (2013). Digitalisering maakt strafrechtspraktijk kleurig. Met alle onbekende gevolgen van dien. Proces, Tijdschrift voor berechting en reclassering, 92(5), 315-317.

Vanderveen, G.N.G. \& Dillen, L. van (in voorbereiding). Systematically photographing gruesome (and mock) crime scenes: the GRIM-database offers visual stimuli for empirical research.

Wistrich, A. J., Guthrie, C., \& Rachlinski, J. (2005). Can Judges Ignore Inadmissible Information? The Difficulty of Deliberately Disregarding. Cornell Law Faculty Publications. Paper 20.

\section{Appendix A Getoonde foto's in de eyetrackingtaak ( $a$ en b) en de casusevaluaties (a-d)}

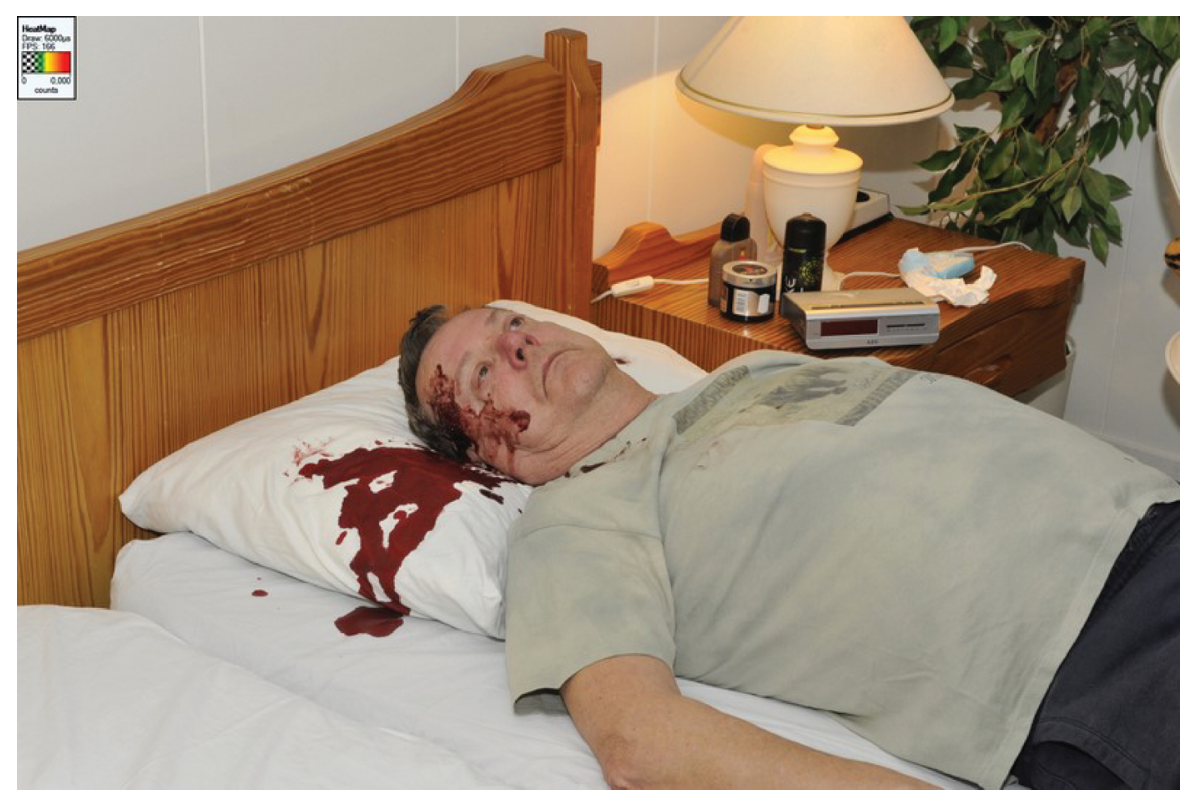



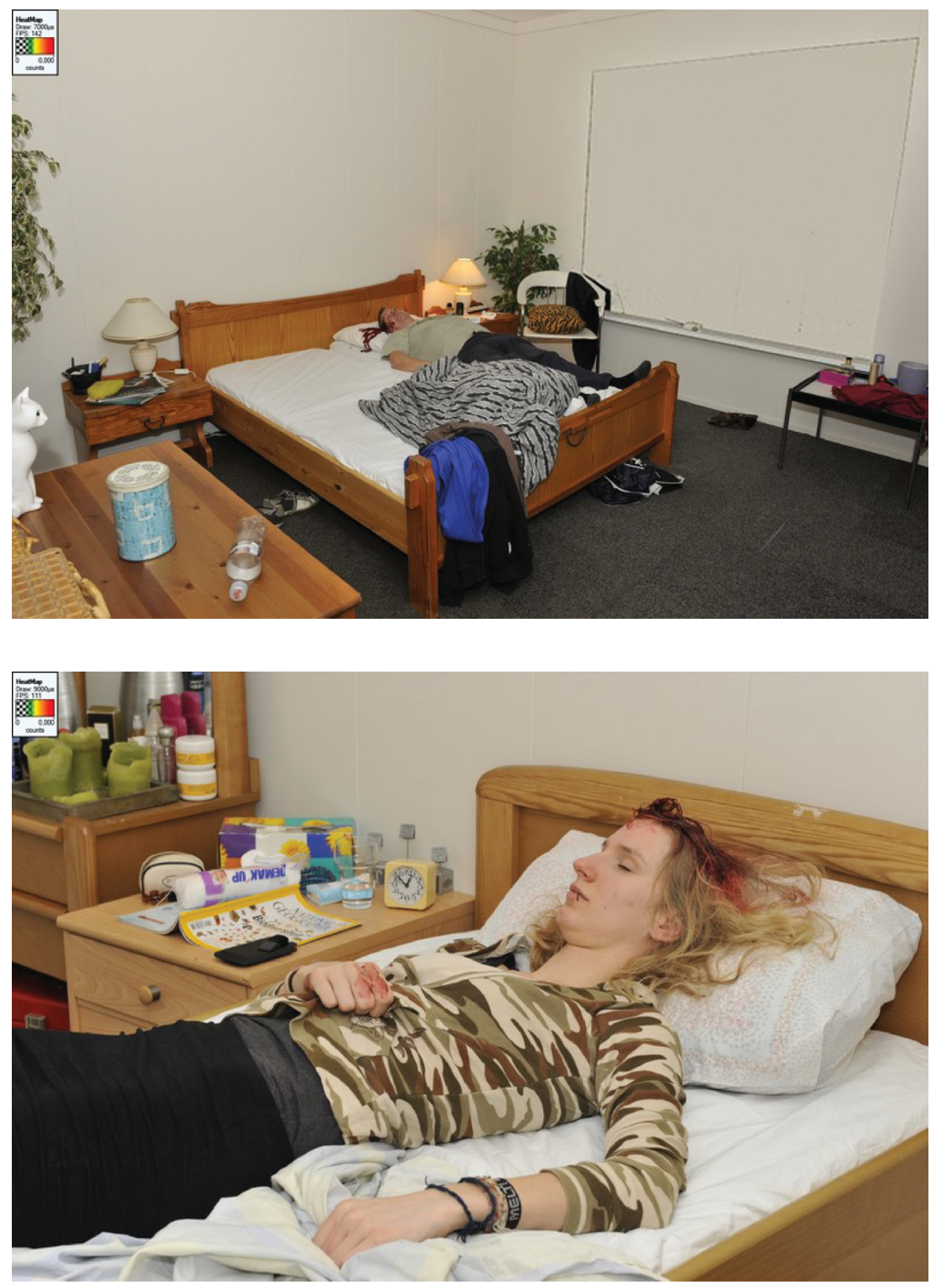


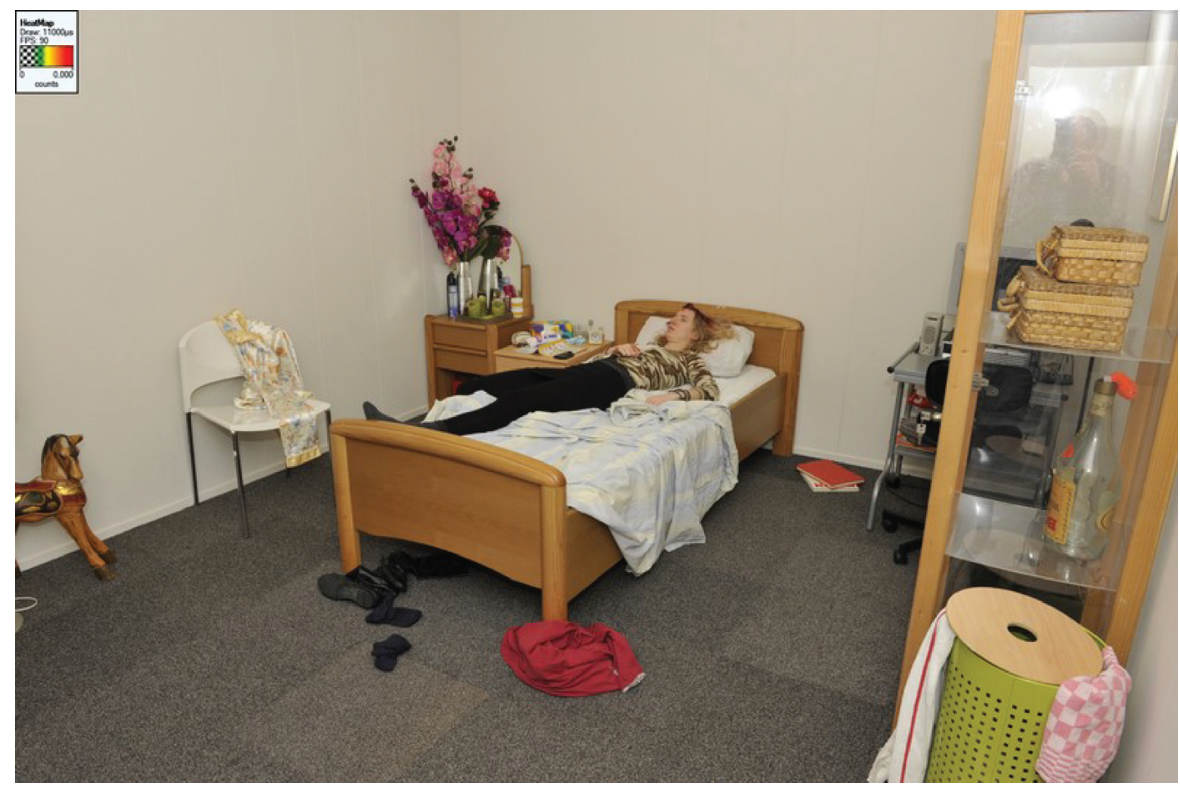

Appendix B Casus omschrijvingen.

\section{Casus 1}

Op maandagochtend krijgt de politie een anonieme tip dat er iemand gewond is geraakt in een huis aan de Moddermanstraat te Leiden. Op het moment dat de politie arriveert, treffen zij het stoffelijk overschot van een 44-jarige man aan. Het forensisch-onderzoeksteam wordt direct ingeschakeld. Het slachtoffer is vermoedelijk door een misdrijf om het leven gekomen. Op de plaats delict kan met redelijk vermoeden worden vastgesteld dat het slachtoffer om het leven is gekomen door een schotwond, maar een vuurwapen is niet gevonden. De forensisch onderzoekers doen het gebruikelijke forensisch-technische onderzoek. Hierbij worden onderstaande foto's gemaakt (foto 1 en 2).

\section{Casus 2}

Op zaterdagmiddag krijgt de politie een melding van een 21-jarige studente in Amsterdam. Toen zij thuiskwam, trof zij haar huisgenoot levenloos aan in bed. Eenmaal gearriveerd op de plaats delict, blijkt het te gaan om het stoffelijk overschot van een 22-jarige vrouw. Forensisch onderzoekers worden daarom ingeschakeld. Er bestaat een zeer sterk vermoeden dat het slachtoffer door een misdrijf om het leven is gekomen. Vermoedelijk is zij aangevallen in de keuken, waarna zij door haar belager in haar bed is gelegd. De forensisch onderzoekers doen het gebruikelijke forensisch-technische onderzoek. Hierbij worden onderstaande foto's gemaakt (foto 3 en 4 ). 